\title{
Make in India: How the campaign stimulated industry led investment in the country and what are the key issues which need to be addressed
}

\author{
Keshav Patel \\ Veer Narmad South Gujarat University \\ Surat, India
}

\begin{abstract}
:
The flagship campaign led by NDA government at the union level has brought many changed perceptions and made the industry and investors across world to consider investing in India. The red carpet for the industry has helped bringing investments into the Indian industrial activities. This work focuses on the campaign as to its relevance and favor to the investors who invested/ want to invest into Indian business sector. This paper tries to evaluate the campaign in the general terms.
\end{abstract}

KEYWORDS: Make in India, Foreign investment in India, Indian corporate sector, Investment

\section{BACKGROUNDER \& EVALUATION:}

Make in India is an activity of the Government of India to support Multinational and domestic organizations to fabricate and manufacture their items in India. It was propelled by Prime Minister Narendra Modi on 25 September 2014. After start of this system, in 2015 India rose as top destination for Foreign Direct Investment surpassing China and the US.

The administration of India is making yet another endeavor to support assembling yield in the nation. Keeping in mind the end goal to draw in speculations into the segment, Prime Minister Narendra Modi dispatched the "Make in India" battle at an occasion a month ago in the capital with top industrialists in participation. Basically, the thought is that higher speculation and movement in the assembling area, from one perspective, will make openings for work for the constantly expanding workforce in the nation and, then again, will turn into the motor of development for the Indian economy. It will be a win-win circumstance. The administration, as indicated by the Make in India site, means to expand the development rate in the part to $12-14 \%$ in the medium term with a specific end goal to push the offer of assembling to around 25\% of the total national output (GDP) by 2022 from the present level of around $16 \%$. 
Interestingly, the thought is not new and endeavors have been made in the past without much achievement and, as an outcome, the offer of assembling is stuck at around 15\% of the GDP for around 30 years.

The administration of India has declared the Foreign Trade Policy (FTP) 2015-20, which concentrates on supporting both the assembling and administrations areas, and lays exceptional accentuation on simplicity of working together change activities in outside exchange. The highly anticipated arrangement goes for expanding fares of merchandise and administrations, work era and expanding quality expansion in the nation, in accordance with the "Make in India" vision.

A standout amongst the most vital activities presented in the new approach is the arrangement of actionables to advance proficiency in foundation use and operations of fare situated units. For instance, EOUs, EHTPs, STPs have been permitted to share infrastructural offices among themselves. This will encourage ideal method for usage of base offices; decrease expense of formation of individual foundation offices by individual units. EOUs have been permitted office to set-up distribution centers close to the port of fare to diminish lead conveyance time.

On the off chance that EOUs/EHTPs/STPs/BPTs source comparative sorts of inputs, the approach permits procurement for entomb unit exchange of such products and administrations. Focal sourcing of inputs will assist diminish with costing of transportation and different logistics expenses, acquire mass rebate and general build viskill of the whole production network.

The strategy backings fare arranged units in their expertise advancement activities having permitted EOUs to have an office to utilize all obligation free hardware and products for training purposes. EOUs having physical fare turnover of Rs 100 million or more have been permitted the office of quick track clearances of import and household acquisition.

\section{MAKE IN INDIA AND SKILL DEVELOPMENT:}

The National Skill Development Corporation has been training around 3 million applicants consistently. The establishment is likewise adapting to meet the administration's desires to produce more gifted skill. Consequent to the dispatch of 'Make in India', the administration has presented the 'Expertise India' program that has eager arrangements of training 500 million Indians by 2020. 'Skill India' will stress training for competitors in diverse territories including land, development, transportation, material, diamond industry, gems planning, managing an account and tourism. The aim is to concentrate on parts where skill advancement is insufficient or nil.

A nation like India requires an in number Public-Private-Partnership (PPP) model to understand the genuine capskill of 'Make in India'. Quality training establishments that are satisfactorily staffed, with great base, satisfactory training apparatuses and upgraded educational modules will help guarantee that the understudies who move on from such foundations are focused. Such representatives will clearly expend less speculations on training.

Professional training and the idea of junior colleges never got validity and authenticity as a result of their natural shortcomings that has prompted quality deficiency and unremarkableness. There are couple of motivators, restricted vision and little creative energy that has gone into the formation of 
these establishments. Abilities advancement through junior colleges needs to concentrate on building respectable professional training establishments.

At long last, interests in assembling must be joined by equivalent interest in human capital. With an expected 300 million youngsters entering the work power somewhere around 2007 and 2025 and a present skill to prepare just 3.1 million a year, expanding India's capacity to give successful aptitudes training remains a tremendous test.

\section{KEY ISSUES:}

India ought to end up a key player on the planet's assembling. In any event, that is the Prime's objective Minister of India, Narendra Modi. In the Make in India Campaign is expressed that India ought to wind up the following assembling powerhouse, a title long held by China. Since the begin of the activity in September a year ago, the administration is occupied with making the nation more alluring for universal financial specialists.

\section{LOWER IMPORT OF HARDWARE}

Following two or three months, it appears like the Make in India Campaign is paying off. One of the focusses of the activity, is to bring down the import of electronic products and rather make them in the nation. This exertion appears to pay off: as of late, Samsung and Sony have reported that they are wanting to set up their assembling base in India. This is a noteworthy underwriting of the Make in India activity.

\section{FABRICATING UNITS SAMSUNG AND SONY}

Samsung is hoping to build up an assembling unit to create cell phones and tablets. An aggregate sum of $\$ 500$ million to $\$ 1$ billion worth of speculations should be possible for this venture. Additionally Sony is wanting to dispatch an Indian fabricating unit for the generation of level board TVs and cell phones. Sony wagers on India to build up long haul development of the organization. Particularly since India is the fourth biggest market for Sony, producing in that nation can cut down expenses and could prompt further extension.

\section{PROMISING AND DEVELOPMENT ARRANGED VISION}

All in all, few conditions must be met so as to end up effective. Since Make in India has a promising and development arranged vision, it can possibly disturb assembling patterns all around.

\section{CONCLUSION:}

A battle like 'Make in India' should be arranged well to guarantee the interest and supply comparisons match. The battle's achievement additionally needs more noteworthy coordinated effort between the state and focal bodies. The concentrate plainly should be on producing particular, talented and a worldwide workforce that can launch India into an assembling center. The street ahead is unrealistic to be simple, particularly when the commitment of assembling to our economy has come down to around 15 for every penny, from its crest level of 16.9 for every penny in 2009 - 2010. Obsolete enactment should be supplanted. A key structure should be set up with an unmistakable guide crosswise over levels. Officials should be given a free hand with their 
advancement checked nearly. More framework should be made as ports, surface transport for 'Make

in India' to succeed. Debasement should be slowed down at all levels to guarantee documents move quick and don't assemble dust for a considerable length of time together.

\section{REFERENCES:}

Topalova, P., \& Khandelwal, A. (2011). Trade liberalization and firm productivity: The case of india. Review of economics and statistics, 93(3), 995-1009.

News Dailies and the Internet. 